\title{
CASE STUDY: Intake and apparent digestibility by beef calves of Alamo and Cave-in-Rock switchgrass cultivars harvested as hay at 3 different maturities
}

\author{
D. Davis, ${ }^{*}$ G. Aiken,† PAS, D. A. Llewellyn, $\ddagger$ K. Lea, $\S$ and S. R. Smith ${ }^{1}$ \\ ${ }^{*}$ Cooperative Extension, University of Kentucky, Lexington 40546; †USDA, ${ }^{2}$ Lexington, KY 40546; łExtension, \\ Washington State University, Kennewick 99336; and §Department of Plant and Soil Science, University of \\ Kentucky, Lexington 40546
}

\begin{abstract}
There has been increased interest in using switchgrass (Panicum virgatum) as a biomass crop. There are several challenges to developing this industry, and these have led to the potential use of switchgrass as hay for feeding beef cattle in Kentucky. The effect of increasing maturity on concentrations of $\mathrm{CP}, \mathrm{NDF}, \mathrm{ADF}$, and other nutritive value indicators of switchgrass hay is well documented, but few in vivo intake and digestibility trials have been conducted to assess this effect on beef cattle performance. The objective of this research was to evaluate the effect of increasing plant maturity on DMI, apparent digestible DMI, and DM digestibility, and to investigate potential challenges for producers when incorporating switchgrass hay into their forage rotation for feeding beef cattle. Two in vivo intake and digestibility trials were conducted in 2011 in which Angus $\times$ Hereford beef steers (199.5 to $264.9 \mathrm{~kg}$ ) were fed ad libitum Alamo and Cave-in-Rock switchgrass harvested as late vegetative, boot, and early flowering hay. Dry matter intake decreased by 1.0 and $0.6 \%$ of BW from late vegetative to early flowering stages with Alamo and Cave-in-Rock cultivars, respectively. Similarly, DM digestibility decreased by 15.9 and $18.5 \%$ and digestible DMI decreased by 1.0 and $0.6 \%$ of BW. Observed decreases in nutritive value, DMI, apparent digestible DMI, and DM digestibility indicate that producers should harvest Alamo and Cave-in-Rock switchgrass before it reaches the boot stage of maturity.
\end{abstract}

\footnotetext{
The authors declare no conflict of interest. ${ }^{1}$ Corresponding author: raysmith1@uky.edu

${ }^{2}$ Mention of trade names or commercial products in the article is solely for the purpose of providing specific information and does not imply recommendation or endorsement by the USDA.
}

Key words: Panicum virgatum, switchgrass, hay quality, in vivo intake, digestibility

\section{INTRODUCTION}

Greater global energy demands have led many to explore bio-based renewable energy sources. Switchgrass (Panicum virgatum) is often considered an ideal biomass crop; it is native to the Great Plains of the United States (Ball et al., 2007), can grow on a range of marginal soils (Berdahl and Redfearn, 2007), and is high yielding. Switchgrass can be used in cellulosic ethanol production or thermal power generation (McLaughlin et al., 1999) via co-firing with coal. A significant challenge to using switchgrass as a renewable energy source remains the high cost relative to fossil fuels (coal) and other biomass crops (Moore et al., 2008).

One significant advantage of switchgrass is that it is a dual-use crop, meaning it can be grown for biomass or forage (hay or grazing). Switchgrass is a warm-season perennial grass that can be grazed in rotation with coolseason grasses and used to mitigate the summer slump that many producers experience when grazing tall fescue [Schedonorus arundinaceus (Schreb.) Dumort.] pastures in the southeastern United States (Rountress et al., 1974). Switchgrass is often considered to be a low-quality forage (Anderson and Matches, 1983; Burns et al., 1997; Berdahl and Redfearn, 2007), and this perception has limited its implementation in forage programs. Research has measured switchgrass forage quality and documented reduced forage quality as the crop matures (Anderson and Matches 1983; Burns et al., 1997), but few studies have investigated the effect of switchgrass maturity in hay when fed to beef cattle. The objective of this research was to evaluate the effect of increasing plant maturity on DMI, apparent digestible DMI (DDMI), and DM digestibility (DMD), and to investigate potential challenges for producers when incorporating switchgrass hay into their forage rotation for feeding beef cattle. 


\section{MATERIALS AND METHODS}

Intake and digestion data were analyzed as a randomized complete block design. Trial and block were treated as random effects.

\section{Intake and Digestibility Feeding Trials}

Two intake and digestibility feeding trials were conducted in 2011 in accordance to the standards determined by the Institution for Animal Care and Use Committee at Eastern Kentucky University (2010-2011). Twenty-four Angus $\times$ Hereford steers (199.6 to $264.9 \mathrm{~kg}$ ) were selected for each of 2 feeding trials. An open feeding barn was converted into a 24-stall feeding facility using corral pens; bunk dividers were constructed to restrict steer access to adjacent bunks. Water and mineral were provided free choice. Pens 2 to 23 were $1.8 \times 3.7 \mathrm{~m}$ and pens 1 and 24 were $1.7 \times 3.7 \mathrm{~m}$ due to design constraints of the barn. Steers were rotated each day through pens to account for pen size variation. To remove variation in $\mathrm{BW}$ as a result of rumen fill, steers were fasted for $24 \mathrm{~h}$, and steer BW was recorded at the beginning of the study, before feeding began.

For both trials, each steer was assigned one treatment of switchgrass (cultivar and plant maturity) and fed for a 7 -d adjustment period and 5-d collection period during which manure and orts were collected. Steers were offered $2.5 \%$ of their BW on $\mathrm{d} 1$, and intake was adjusted daily with a goal of $15 \%$ DM as orts (refused feed). Orts were weighed each day and subsampled for laboratory analysis. Throughout the collection period, daily DMI was noted for each steer. The acid detergent insoluble ash internal marker ratio (feed going in:fecal output) was used to calculate digestibility. Steers were placed in a confinement chute in the same order each day, and grab samples of manure were collected each day, 14 to $15 \mathrm{~h}$ following feeding.

\section{Hay Harvest}

Alamo, a lowland switchgrass cultivar, was harvested from the University of Kentucky Spindletop Research Farm in Lexington, Kentucky, and Cave-in-Rock, an upland cultivar, was harvested from the University of Kentucky Eden Shale Research Farm near Owenton, Ken- tucky. Nitrogen was applied at a rate of $67.2 \mathrm{~kg} / \mathrm{ha}$ at Eden Shale on April 20, 2010, and May 10, 2011, and at the same rate at Spindletop on April 20, 2010, and May 3, 2011. Soil samples indicated that $\mathrm{pH}, \mathrm{P}$, and $\mathrm{K}$ were adequate based on University of Kentucky recommendations (AGR-201); therefore, no additional soil amendments were needed. Herbicide (2-4 dichlorophenoxyacetic acid) was applied $(0.44 \mathrm{~kg} / \mathrm{ha}$ on an active ingredient basis) both years in early April to control broadleaf weeds. In 2011 approximately one-half of the Alamo stand was harvested while in the vegetative stage (June 6), one-fourth while in the boot stage (June 16), and one-fourth while in the early flowering stage (June 25). Cave-in-Rock was harvested in a similar manner on May 31, June 10, and July 25, respectively, in 2011; unequal subdivisions of the stands were necessary to ensure adequate amounts of harvested hay for feeding from each of the 3 plant maturities because harvesting earlier produced less yield per hectare than later harvests. The mower-conditioner (Model 540, John Deere, Moline, IL) was modified to harvest at a cutting height of $15 \mathrm{~cm}$. A standard trailing bar rake (Model 670, John Deere) and round baler (Model 569, John Deere) were used to bale material after field drying to $18 \%$ moisture or lower. Sample cores were taken from each harvest using the Penn State forage sampler (Nasco, Fort Atkinson, WI). Bales were stored inside for the remainder of the season. Before feeding, hay was tub ground to approximately 15 -cm stem length and stored inside in individual bunks.

\section{Laboratory Analysis}

Manure and orts were dried at $70^{\circ} \mathrm{C}$ using a forced-air dryer following collection. Manure, hay, and orts were initially ground to pass a $2-\mathrm{mm}$ screen in a Wiley Mill (Thomas Scientific, Swedesboro, NJ) and later ground to pass 1-mm screen in a Cyclone Mill (Udy Corporation, Fort Collins, CO). Dry matter was determined for hay, orts, and feces. Crude protein was determined using combustion (AOAC 1995; method no. 990.03, Nitrogen Analyzer model FP-528, LECO Corporation, St. Joseph, MI). Acid detergent fiber and NDF of hay, orts, and feces were determined with a fiber analyzer using a modification of methods as described by Van Soest et al. (1991) and Komarek and Sirois (1993), respectively. The acid detergent

Table 1. Percentage DM, CP, NDF, and ADF for Alamo switchgrass hay harvested at 3 different stages of maturity in 2011

\begin{tabular}{lcccc} 
Item, \% of DM & Late vegetative & Boot & Early flowering & SEM \\
\hline DM & $90.2^{a}$ & 90.4 & 91.0 & 0.13 \\
CP & $13.5^{\mathrm{a}}$ & $7.5^{\mathrm{b}}$ & $5.1^{\mathrm{c}}$ & 0.64 \\
NDF & $59.0^{\mathrm{c}}$ & $62.2^{\mathrm{b}}$ & $64.0^{\mathrm{a}}$ & 0.10 \\
ADF & $29.9^{\mathrm{c}}$ & $36.7^{\mathrm{b}}$ & $39.9^{\mathrm{a}}$ & 0.56 \\
\hline
\end{tabular}

a-c Values with matching superscripts are not statistically different $(P<0.05)$. 
Table 2. Percentage DM, CP, NDF, and ADF for Cave-in-Rock switchgrass hay harvested at 3 different stages of maturity in 2011

\begin{tabular}{lcccc} 
Item, \% of DM & Late vegetative & Boot & Early flowering & SEM \\
\hline DM & 90.1 & 90.6 & 91.2 & 0.13 \\
CP & $11.3^{\mathrm{a}}$ & $5.5^{\mathrm{b}}$ & $4.8^{\mathrm{c}}$ & 0.64 \\
NDF & $57.1^{\mathrm{c}}$ & $64.4^{\mathrm{b}}$ & $65.1^{\mathrm{a}}$ & 0.10 \\
ADF & $29.2^{\mathrm{c}}$ & $38.6^{\mathrm{b}}$ & $40.5^{\mathrm{a}}$ & 0.56 \\
\hline
\end{tabular}

${ }^{a-c}$ Values with matching superscripts are not statistically different $(P<0.05)$.

insoluble ash in the hay, orts, and feces was determined by ashing at $525^{\circ} \mathrm{C}$ for $12 \mathrm{~h}$. All samples were analyzed in duplicate with an acceptable variation of $5 \%$ between duplicates. Daily DMI was determined for each steer by subtracting the weight of the orts (DM) from the weight of the feed (DM). Apparent DMD was calculated using partial manure collection and acid detergent insoluble ash as an internal marker when intake is known in accordance with procedures outlined by Cochran and Galyean (1994).

\section{Statistical Analysis}

All forage quality data were analyzed using ANOVA procedures of SAS (SAS Institute Inc., Cary, NC). Because Alamo and Cave-in-Rock cultivars were harvested at separate locations, each cultivar was analyzed separately using GLM procedures. Mean CP, NDF, and ADF responses were calculated using least squares means, and the least-significant differences $(P<0.05)$ procedure was used for treatment comparisons. Intake and digestion data were analyzed as a randomized complete block design using the MIXED procedure in SAS. For each trial, there were 12 steers for each cultivar (Alamo and Cave-in-Rock) with 4 steers assigned to each maturity. Steers were blocked by steer weight, and new steers were randomized for each trial. Animal was considered an independent variable; block and trial were treated as random effects. Treatment means for DMI, apparent DMD, and DDMI were calculated using the LSMEANS procedure in SAS. Least squares means for DMI, apparent DMD, and DDMI were compared among treatments using the PDIFF option of SAS.

\section{RESULTS AND DISCUSSION}

\section{Forage Analysis}

A significant plant maturity effect $(P<0.0001)$ was observed for CP, NDF, and ADF for both Alamo and Cavein-Rock switchgrass, with the early-maturity harvests containing the greatest $\mathrm{CP}$ and least NDF and ADF (Tables 1 and 2).

The CP requirement for steers $(250 \mathrm{~kg})$ has been estimated at $0.45 \mathrm{~kg} / \mathrm{d}$ to support $1 \mathrm{~kg}$ of $\mathrm{BW}$ gain per day (NRC, 1996). Switchgrass hay harvested after the early vegetative stage for both cultivars did not meet this criterion. Increases in NDF have been associated with limiting intake (Van Soest, 1987; Mertens, 1994) and increases in ADF have been associated with declines in DMD (Van Soest, 1987). For both cultivars, the greatest increase $(P$ $<0.05)$ in NDF and ADF occurred as harvest was delayed from the late vegetative to the boot stage of growth. Therefore, delaying switchgrass hay harvest until the stand reaches the early reproductive stage resulted in a significant reduction in forage quality.

\section{DMI}

Average DMI of Alamo hay was estimated at 2.2, 1.3, and $1.2 \%$ of $\mathrm{BW} /$ steer per day consuming late vegetative, boot, and early flowering hays, respectively (Table 3 ), with the hay harvested in the late vegetative stage having greater DMI $(P<0.0001)$ compared with the boot and early flowering stages of growth. Average DMI of Cave-

Table 3. Forage analysis for 3 maturities of Alamo switchgrass hay over 2 feeding trials in 2011

\begin{tabular}{lcccc} 
Item $^{1}$ & Late vegetative & Boot & Early flowering & SEM \\
\hline Daily DMI, \% of BW & $2.2^{\mathrm{a}}$ & $1.3^{\mathrm{b}}$ & $1.2^{\mathrm{b}}$ & 0.142 \\
Apparent DMD, \% & $72.6^{\mathrm{a}}$ & $61.6^{\mathrm{b}}$ & $56.7^{\mathrm{c}}$ & 3.23 \\
DDMI, \% of BW & $1.7^{\mathrm{a}}$ & $0.8^{\mathrm{b}}$ & $0.7^{\mathrm{b}}$ & 0.11 \\
\hline
\end{tabular}

a-c Values with matching superscripts are not statistically different $(P<0.05)$.

${ }^{1} \mathrm{DMD}=\mathrm{DM}$ digestibility; DDMI = digestible DMI. 
Table 4. Forage analysis for 3 maturities of Cave-in-Rock switchgrass hay over 2 feeding trials in 2011

\begin{tabular}{lcccl} 
Item $^{1}$ & Late vegetative & Boot & Early flowering & SEM \\
\hline Daily DMI, \% of BW & $1.9^{\mathrm{a}}$ & $1.6^{\mathrm{ab}}$ & $1.3^{\mathrm{b}}$ & 0.142 \\
Apparent DMD, \% & $70.0^{\mathrm{a}}$ & $67.7^{\mathrm{a}}$ & $51.5^{\mathrm{b}}$ & 3.23 \\
DDMI, \% of BW & $1.3^{\mathrm{a}}$ & $1.2^{\mathrm{a}}$ & $0.7^{\mathrm{b}}$ & 0.081 \\
\hline
\end{tabular}

${ }^{a, b}$ Values with matching superscripts are not statistically different $(P<0.05)$.

${ }^{1} \mathrm{DMD}=\mathrm{DM}$ digestibility; DDMI = digestible DMI.

in-Rock hay was $1.9,1.6$, and $1.3 \%$ of BW/steer per day at the late vegetative, boot, and early flowering stages, respectively, with the hay harvested in the late vegetative stage of growth greater than early flowering $(P<0.0001)$, and both late vegetative and early flowering were similar to the boot stage (Table 4). The results indicate that the daily DMI of Alamo and Cave-in-Rock switchgrass harvested in the late vegetative stage of growth should not be a limitation for steer BW gain (Burns et al., 1997), but delaying harvest to the later stages of maturity reduces DMI substantially.

\section{DMD}

Apparent DMD of Alamo hay was estimated at 72.6, 61.6 , and $56.7 \%$ for late vegetative, boot, and early flowering stages, respectively, and 70.0, 67.7, and 51.5\%, respectively, for Cave-in-Rock. There was a maturity effect $(P<$ 0.0001) on apparent DMD for both Alamo and Cave-inRock. The greatest apparent DMD $(P<0.05)$ of Alamo was observed for the late vegetative hay, followed by the boot and early flowering stages (Table 3). Apparent DMD of the Cave-in-Rock early flowering hay was less $(P<$ $0.05)$ than the other 2 maturities, but it did not differ $(P$ $>0.05$ ) between the late vegetative and boot stage (Table 4). The different trends of apparent DMD for steers that consumed Alamo and Cave-in-Rock switchgrass in this study are likely due differences in leaf-to-stem ratio of upland and lowland type switchgrasses. The maturity effect was not as pronounced in early hay harvests for Cave-inRock, likely due to the physiological growing characteristics. Cave-in-Rock has a wider window of harvest, which gives more flexibility in harvest management, and still maintains adequate DMD.

\section{DDMI}

The daily DDMI of Alamo hay by beef steers was 1.7, 0.8 , and $0.7 \%$ of $\mathrm{BW} / \mathrm{d}$ for the late vegetative, boot, and early flowering stages, respectively. For Cave-in-Rock, daily DDMI by beef steers was $1.3,1.2$, and $0.7 \%$ of BW ( $P$ $<0.05)$. Maturity had an effect $(P<0.0001)$ on DDMI of steers consuming both Alamo and Cave-in-Rock (Tables 3 and 4). Apparent DDMI of Alamo decreased by half as harvest was delayed from the late vegetative stage to the boot stage, and for Cave-in-Rock, apparent DDMI decreased by half from the boot to early flowering stage.

\section{IMPLICATIONS}

These findings support previous work showing that forage quality and intake by beef cattle is greatly reduced when switchgrass is harvested after the late vegetative stage. Furthermore, the low forage quality, DMI, and apparent digestibility of either cultivar is likely to result in suboptimal performance in feeder calves. Additional research may indicate that well-managed switchgrass harvested in the late vegetative stage is adequate for dry beef cows (Burns et al., 1997). Another study has suggested that switchgrass in a rotational grazing system produces acceptable gains (Keyser et al., 2012) in beef steers (0.9 $\mathrm{kg} / \mathrm{d}$ ). After grazing, the stand was allowed to regrow and harvested for biomass. This work further supports the findings of Brejda et al. (1994) in that the ability to graze or harvest hay from switchgrass allows beef cattle producers a transition period as biomass infrastructure and demand increase in the future.

\section{ACKNOWLEDGMENTS}

Funding for this project was provided in part by the Kentucky Governor's Office of Agricultural Policy, the Kentucky Agriculture Development Fund, and the Eastern Kentucky University (EKU) Center for Renewable and Alternative Fuel Technologies (CRAFT). The authors also thank Bruce Pratt (EKU) and members of the University of Kentucky Forage Extension group, CRAFT research team, EKU Meadowbrook Farm staff, and University of Kentucky farm management crew.

\section{LITERATURE CITED}

Anderson, B. A., and A. G. Matches. 1983. Forage yield, quality, and persistence of switchgrass and caucasian bluestem. Agron. J. 75:119-124.

AOAC International. 1995. Official Methods of Analysis. 16th ed. AOAC Int., Arlington, VA. 
Ball, D. M., C. S. Hoveland, and G. D. Lacefield. 2007. History of southern forage crops. Pages $1-7$ in Southern Forages. 4th ed. Int. Plant Nutr. Inst., Lawrenceville, GA.

Berdahl, J. D., and D. D. Redfearn. 2007. Grasses for arid and semiarid areas. Pages 231-234 in Forages: The Science of Grassland Agriculture. 6th ed. R. F. Barns, C. J. Helson, K. J. Moore, and M. Collins, ed. Blackwell Publ., Ames, IA.

Brejda, J. J., J. R. Brown, G. W. Wyman, and W. K. Schumacher. 1994. Management of switchgrass for forage and seed production. J. Range Manage. 47:22-27.

Burns, J. C., K. R. Pond, D. S. Fisher, and J. M. Luginbuhl. 1997. Changes in forage quality, ingestive mastication, and digesta kinetics resulting from switchgrass maturity. J. Anim. Sci. 75:1368-1379.

Cochran, R. C., and M. L. Galyean. 1994. Measurement of in vivo forage digestion by ruminants. Pages $613-643$ in Forage Quality, Evaluation, and Utilization. G. C. Fayey Jr., M. C. Collins, D. R. Mertens, and L. E. Moser, ed. Am. Soc. Agron.-Crop Sci. Soc. Am.-Soil Sci. Soc. Am., Madison, WI.

Keyser, P., G. Bates, J. Waller, C. Harper, and E. Doxon. 2012. Grazing Native Warm Season Grasses in the Mid-South (SP 731-C). Univ. Tennessee Coop. Ext. Serv., Knoxville, TN.

Komarek, A. R., and P. Sirois. 1993. A filter bag procedure for improved efficiency of fiber analysis. J. Dairy Sci. 76(Suppl. 1):309. (Abstr.)

McLaughlin, S., J. Bouton, D. Dransby, B. Conger, W. Ocumpaugh, D. Parrish, C. Taliaferro, K. Vogel, and S. Wullschleger. 1999. Devel- oping switchgrass as a bioenergy crop. Pages 282-299 in Perspectives on New Crops and New Uses. J. Janick, ed. ASHS Press, Alexandria, VA.

Mertens, D. R. 1994. Regulation of forage intake. Pages 450-493 in Forage Quality, Evaluation, and Utilization. G. C. Fayey Jr., M. C. Collins, D. R. Mertens, and L. E. Moser, ed. Am. Soc. Agron.-Crop Sci. Soc. Am.-Soil Sci. Soc. Am., Madison, WI.

Moore, K. J., S. L. Fales, and E. A. Heaton. 2008. Bio-renewable energy: New opportunities for grassland agriculture. XXI International Grassland Congress Proceedings, Guangzhou, China. Accessed Nov. 15, 2017. https://www.cabdirect.org/cabdirect/abstract/ 20093270729.

NRC. 1996. Nutritional Requirements of Beef Cattle. 7th ed. Natl. Acad. Press, Washington, DC.

Rountress, B. H., A. G. Matches, and F. A. Martz. 1974. Season too long for your grass pasture? Crop Soils 26:7-10.

Smith, S. R., L. Schwer, T. Keene, and K. Sena. 2011. Switchgrass for Biomass Production in Kentucky (AGR-201). Coll. Agric., Univ. Kentucky, Lexington, KY.

Van Soest, P. J. 1987. Nutritional Ecology of the Ruminant. Pages 39-57. Cornell Univ. Press, Ithaca, NY.

Van Soest, P. J., J. B. Robertson, and B. A. Lewis. 1991. Methods for dietary fiber, neutral detergent fiber, and non-starch polysaccharides in relation to animal nutrition. J. Dairy Sci. 74:3583-3597. 